\title{
PERAN NEGARA DALAM PELAKSANAAN JAMINAN PRODUK HALAL
}

\author{
Ralang Hartati \\ Fakultas Hukum Universitas Tama Jagakarsa \\ Email: ralanghartati@yahoo.com
}

\begin{abstract}
ABSTRAK
Penelitian ini meneliti mengenai pelaksanaan Pasal 4 UU No. 3 tahun 2014 tentang jaminan produk halal, yang hingga tahun 2019 belum efektif berlaku. Dalam UU No. 33 Tahun 2004 tentang Jaminan Produk Halal ini, belum diatur Sanksi hukum untuk pelaku usaha yang tidak mengajukan sertifikasi. Sehingga perlu dipertanyakan Bagaimana peran Negara dalam pelaksanaan Pasal 4 dan Bagaimana sanksi Pidana atas Pelanggaran Pelaksanaan Jaminan Produk halal. Jenis Penelitian adalah yuridis normative dan empiris, menggunakan penelitian kepustakaan yang disertai dengan penelitian lapangan melalui wawancara kepada fihak yang berwenang di BPJPH dan membagi kuesioner kepada 60 responden muslim secara acak. Hasil penelitian dapat dijelaskan bahwa peran negara yang menangani masalah Kehalalan suatu produk adalah lembaga MUI (Majelis Ulama Indonesia). Mulai Oktober 2017,Sejak diundangkannya UU. No. 33 Tahun 2014 tentang Jaminan Produk Halal wewenang tersebut dialihkan kepada Badan Penyelenggara Jaminan Produk Halal (BPJPH). Sanksi Pidana bagi pelanggaran pasal 4, yang terdapat dalam Pasal 56 dan Pasal 57 UU JPH, hanya diberlakukan terhadap pelaku orang perseorangan. Oleh itu, ketentuan atau norma pidana atas Jaminan Produk Halal, merupakan peraturan tentang hukuman akibat pelanggaran kewajiban moral hazard dari subjek hukum pribadi atau korporasi.
\end{abstract}

Kata kunci: Peran Negara dan Jaminan Produk Halal

\begin{abstract}
This study researched implementation of Article 4 of Law No. 3 of 2014, until 2019, this law has not been effective. In Law No. 33 of 2004 concerning Halal Product Guarantees, legal sanctions have not been regulated for businessmen that do not apply for certification yet. So that it needs to be questioned how the role of the State in the implementation of Article 4 and How Criminal Sanctions of the violated implementation of Halal Products Guarantees. This research is normative and empirical juridical, using library research and field research through interviews with authorized parties at BPJPH and randomly distributing questionnaires to 60 Muslim respondents. The results of his research are since the promulgation of Law No. 33 of 2014, the authority to deal with halal issues is a product switched from the Indonesian Ulema Council (MUI to the Halal Product Guarantee Agency (BPJPH). Criminal sanctions for violations of article 4, which are contained in Article 56 and Article 57 of the JPH Law, apply to perpetrators of individuals, which are regulations concerning penalties of consequence violations of moral hazard obligations from subjects of personal or corporate law.
\end{abstract}

Keyword: Role of the state, Halal Product Guarantees 


\section{PENDAHULUAN}

Berdasarkan teori geopolitik Frederich Ratzel, ${ }^{1}$ dalam "memperluas wilayah kedaulatan dimungkinkan suatu negara melakukan ekspansi, dan ekspansi yang diperkenankan adalah melalui perdagangan dan industri." Dan banyak negara melakukan ekspansi, seperti RRC, Korea, Jepang dibidang perdagangan dan industri, terutama pada era perdagangan bebas. Indonesia adalah salah satu negara menjadi sasaran dari ekspansi negara-negara tersebut. Hal ini terlihat dengan membanjirnya barang-barang dari luar negara yang beredar di Indonesia. Ada barang-barang yang berupa pakaian, obat, kosmetik dan makanan dan minuman. Dan barang-barang yang masuk tersebut bukanlah barang yang bersertifikat halal.

Indonesia adalah negara yang mayoritas konsumennya adalah beragama Islam, dengan masuknya barang-barang tersebut yang berasal dari negara non muslim, maka akan menimbulkan masalah bagi konsumen Islam. Kekuatiran akan produk makanan dan/atau minuman tersebut halal atau tidak masih menjadi hal yang dipersoalkan di kalangan umat muslim.Dan ini menjadi tugas negara untuk memberi perlindungan kepada pemakai produk yang berasal dari luar Indonesia.

Untuk menjamin kepastian hukum atas perlindungan bagi pemakai produk makanan baik yang berasal dari produksi dalam negeri maupun yang berasal dari import negara lain, pemerintah menetapkan berlakunya Undang-Undang No.33 tahun 2014 tentang Jaminan Produk Halal (selanjutnya disebut dengan UU JPH), dengan maksud agar kesinambungan proses produksi halal dijamin oleh produsen dengan cara menerapkan Sistem Jaminan Halal, artinya bahwa seorang produsen harus dapat menjamin bahwa produk makanan dan/minuman yang diproduksi dan/atau diperdagangkannya harus memiliki sertifikat halal. Ini berarti menimbulkan kewajiban bagi setiap produsen untuk melakukan sertifikasi halal atas produknya, agar tercipta perlindungan hukum bagi pemakai produk tersebut.

Sebelum berlakunya Undang-Undang No.33 Tahun 2014 tentang Jaminan Produk Halal (JPH) tersebut, sertifikasi halal atas suatu produk dilaksanakan oleh Majelis Ulama Indonesia, yang beroperasi sejak 6 Januari 1989 dan diakui secara

${ }^{1}$ Tim Dosen Kewarganegaraan, Modul Pendidikan Kewarganegraan Untuk Mahasiswa, [Jakarta :Dikti, 2016], hlm.157 
luas diberbagai belahan dunia dan dikenal paling ketat ${ }^{2}$. Dimana pada masa itu, belum banyaknya pelaku usaha melakukan sertifikasi halal atas produk yang mereka masukkan, produksi dan/atau yang mereka perdagangkan. Hal ini terlihat dengan masih banyaknya konsumen yang kuatir akan kehalalan suatu produk, terutama terhadap produk-produk yang datang dari luar negeri.

Dengan disahkannya UU JPH tersebut diharapkan kekuatiran konsumen akan produk halal dapat teratasi, dimana Pasal 4 UU JPH mewajibkan pelaku usaha produk makanan dan atau minuman untuk melakukan sertifikasi kehalalan produknya. Terhitung 2019 sertifikasi halal dipegang oleh Kementerian Agama, tidak lagi di $\mathrm{MUI}^{3}$ artinya bahwa sertifikisasi halal tidak lagi menjadi kewenangan MUI secara mutlak. MUI tetap dilibatkan dalam penerbitan sertifikasi halal ini. MUI sebagai auditor terhadap produk yang didaftarkan.

Setelah masa sosialisai lima tahun dari sejak undang-undang tersebut disahkan, maka tahun 2019 menjadi keharusan bahwa setiap produk makanan harus sudah bersertifikat halal yang akan dilakukan oleh Kemenag. ${ }^{4}$ Sertifikasi halal akan dilaksanakan oleh Badan Penyelenggara Jaminan Produk Halal (BPJPH) yang didirikan pada tanggal 11 Oktober $2017^{5}$, yang nanti akan bekerjasama dengan MUI sebagai auditor terhadap produk yang didaftarkan, dan Lembaga Pemeriksa Halal yang berwenang melakukan pemeriksaan dan/atau pengujian kehalalan. Kesemua lembaga ini berada dibawah kewenangan Kemeterian Agama.

Namun apabila ditelaah lebih lanjut UU JPH tersebut dapat dilihat bahwa untuk terlaksananya Pasal 4 UU JPH tersebut, maka harus ada peran pemerintah dan/atau masyarakat untuk menegakkan aturan tersebut, dengan mendirikan Lembaga Pemeriksa Halal, yang membantu tugas BPJHP untuk melakukan pemeriksaan dan/atau pengujian kehalalan Produk.Berdasarkan Pasal 13 UU JPH, LPH dibentuk oleh masyarakat, yang diajukan oleh lembaga keagamaan Islam, dan berbadan hukum. Dan untuk mendirikan LPH tersebut undang-undang

\footnotetext{
2 http://www.tribunnews.com/bisnis/2017/10/14/mulai-2019-sertifikasi-halal-dipegangkemenag-tidak-lagi-di-mui, diakses tgl. 16 Maret 2018 ${ }^{3}$ Ibid

${ }^{4}$ http://www.tribunnews.com/bisnis/2017/10/13/mulai-2019-sertifikasi-produk-halal-jadikewajiban-dan-akan-dijalankan-kemenag.diakses tgl 19 Mei 2018

${ }^{5}$ http://www.tempo.co/bisnis/2017/10/15/Pemerintah Bentuk BPJPH, Ini Cara Mendapatkan Sertifikat Halal, diakses tgl. 19 Maret 2018
} 
mensyaratkan harus adanya laboratorium yang harus dimiliki oleh lembaga tersebut, dan itu perlu adanya modal yang besar untuk mendirikan LPH tersebut.

Hal inilah yang nantinya dapat menjadi kendala dalam pendirian LPH tersebut sebagai lembaga yang bertugas memeriksa apakah produk tersebut halal atau tidak. Dan dalam penelitian ini peneliti mencoba untuk melihat peran pemerintah dalam pendirian LPH sebagai amanat UU No.33 Tahun 2014, yang peneliti tuangkan dalam penelitian peneliti dengan judul " Peran pemerintah dalam pelaksanaan Jaminan Produk Halal". Adapun permasalahan dalam penelitian ini adalah:

1.Bagaimana peran pemerintah dalam melaksanakan Pasal 4 UU No.33

Tahun 2014 tentang Jaminan Produk Halal ?

2.Bagaimana Sanksi Pidana apabila terjadi pelanggaran pelaksanaan Jaminan Produk Halal

Penelitian ini bersifat penelitian deskritif prespektif, yang bertujuan memaparkan tentang peran negara dalam mewujudkan terlaksananya Pasal 4 Undang-Undang No.33 Tahun 2014. Metode pendekatan yang digunakan dalam menjawab permasalahan yang ada dalam penelitian ini adalah metode pendekatan normative empiris, dengan melihat proses pelaksanaan setifikasi halal terhadap produk-produk makanan yang beredar dan diperdagangkan di wilayah hukum Indonesia.

\section{PEMBAHASAN}

\section{A. Kehalalan dalam Islam}

Dalam QS. Al-Baqarah ayat : 168 yang menentukan, bahwa Allah SWT mensyari'atkan untuk kita memakan makanan yang halal lagi baik dari apa yang terdapat di bumi. Selanjutnya QS Al-Baqarah, ayat 173 menentukan : bahwa makanan yang haram dimakan adalah bangkai, darah, babi dan binatang yang disembelih tanpa menyebut nama Allah SWT. Ketentuan ini menimbulkan keinginan umat muslim untuk selalu memperhatikan produk yang mereka beli dan/atau konsumsi dengan selalu melihat apakah pada produk tersebut tertera label halal atau tidak. Menurut Jhering, ${ }^{6}$ kepentingan sebagai sesuatu yang menentukan dalam hukum, khususnya kepentingan masyarakat. Karenanya

${ }^{6}$ Bernard L.Tanya, Teori Hukum : Strategi Tertib Manusia Lintas Ruang dan Generasi, (Yogyakarta : Genta, 2010), hlm.110 
hukum bertugas menata secara imbang dan serasi antara kepentingan-kepentingan tersebut.

Salah satu keseimbangan dan keserasian yang perlu ditata oleh hukum adalah keseimbangan kepentingan antara pengguna produk dengan pelaku usaha yang memiliki produk tersebut. Dan untuk mewujudkan kesimbangan perlindungan kepentingan konsumen dan pelaku usaha sehingga tercipta perekonomian yang sehat diperlukan perangkat peraturan perundang-undangan, salah satunya adalah Undang-udang No.8 Tahun 1999 tentang Perlindungan Konsumen, yang dimaksudkan untuk melindungi konsumen atas produk yang digunakannya atau dikonsumsinya sehinggga tidak timbul rasa kekhawatiran atas mengkonsumsi produk makanan dan/atau minuman.

Untuk terlaksananya perlindungan tersebut, Stammler $^{7}$ mengatakan bahwa "orang mau berbuat sesuatu, pasti untuk mengejar suatu tujuan" artinya tujuan menentukan perbuatan. Perbuatan sebagai materi diberi bentuknya oleh tujuan yang dikehendaki. Jadi dalam mencapai tujuan melindungi konsumen untuk mendapatkan rasa aman atas produk yang dikonsumsinya maka harus ada perbuatan dari pelaku usaha untuk memberikan perlindungan itu berupa tindakan mensertifikat produknya sebagai produk yang halal untuk dikonsumsi oleh konsumen muslimin.

Untuk mewujudkan tindakan pelaku usaha tersebut, maka negara menciptakan seperangkat aturan, yakni dengan mensahkan Undang-Undang No.33 Tahun 2014 tentang Jaminan Produk Halal. Namun itu bukan berarti tindakan negara dalam mewujudkan tindakan pelaku usaha tersebut tidak berhenti sampai dengan disahkan undang-udang tersebut, ada tindakan lain yang harus dilakukan oleh negara sebagai menjamin hak-hak dasar manusia, yaitu hak atas rasa aman dalam mengkonsumsi produk.

Tindakan yang harus dilakukan oleh negara sebagai bentuk perlindungan pada hak konsumen terhadap kehalalan suatu produk adalah segera membentuk Lembaga Pemeriksa Halal yang selanjutnya disingkat LPH adalah lembaga yang melakukan kegiatan pemeriksaan dan/atau pengujian terhadap kehalalan produk. Terbentuknya lembaga tersebut berdasarkan Pasal 12 Undang-undang No.33

\footnotetext{
${ }^{7}$ Ibid, hlm. 124
} 
Tahun 2014, merupakan kerjasama antara pemerintah dan masyarakat, dan berdasarkan Pasal 13 LPH ini harus diajukan oleh lembaga keagamaan Islam berbadan hukum, yang harus memiliki 3 (tiga) orang auditor halal dan memiliki laboratorium atau kesepakatan kerja sama dengan lembaga lain yang memilikilaboratorium.

Jadi disinilah peran negara, yakni memback-up terbentuknya lembaga tersebut sehingga pelaksanaan sertifikasi halal atas suatu produk yang diproduksi dan atau yang masuk ke dalam negara, sebagai perwujudan perlindungan terhadap penggunaan produk, sehingga terwujudnya peran negara yaitu melindungi setiap warganegara untuk mencapai keadilan sosial.

\section{B. Analisis Pasal 4 UU No.33 Tahun 2004 Tentang Jaminan Produk Halal.}

Sertifikasi halal di Indonesia dalam perkembangan terakhir mengalami pergeseran. Jika selama ini sertifikasi halal ditangani oleh LPPOM MUI yang merupakan lembaga swadaya masyarakat, sejak lahirnya UU Jaminan Produk Halal, penanganan sertifikasi menjadi wewenang negara melalui Badan Penyelenggara Jaminan Produk Halal (BPJPH). MUI memang masih memiliki kewenangan untuk menetapkan halal dan haram. Tetapi proses formalnya, baik pemeriksaan saintifiknya maupun dikeluarkannya sertifikat menjadi wewenang BPJPH.

Untuk menjamin setiap pemeluk agama beribadah dan menjalankan ajaran agamanya, Negara berkewajiban memberikan pelindungan dan jaminan tentang kehalalan Produk yang dikonsumsi dan digunakan masyarakat. Jaminan mengenai Produk Halal hendaknya dilakukan sesuai dengan asas perlindungan, keadilan, kepastian hukum, akuntabilitas dan transparansi, efektivitas dan efisiensi, serta profesionalitas. Oleh karena itu, jaminan penyelenggaraan Produk Halal bertujuan memberikan kenyamanan, keamanan, keselamatan, dan kepastian ketersediaan Produk Halal bagi masyarakat dalam mengonsumsi dan menggunakan Produk, serta meningkatkan nilai tambah bagi Pelaku Usaha untuk memproduksi dan menjual Produk Halal. ${ }^{8}$

\footnotetext{
${ }^{8}$ Isi Penjelasan UU NO.33 tahun 2014 Tentang Jaminan Produk Halal
} 


\section{Pasal 4 UU JPH menyebutkan :}

“ Produk yang masuk, beredar, dan diperdagangkan di wilayah Indonesia wajib bersertifikat halal."

Isi pasal ini bukan diartikan bahwa setiap produk yang dijual oleh pengusaha harus halal dan bukan tidak boleh memperdagangkan yang tidak halal atau haram menurut agama Islam, tetapi maksud dari isi Pasal 4 adalah para pengusaha boleh meperdagangkan barang yang tidak halal, tetapi harus disebutkan bahwa barang tersebut tidak halal. Ketika sudah mendapatkan label halal harus mempertahankan kehalalannya dan menjaga kehalalannya. Intinya para pengusaha bukan tidak boleh memperdagangkan barang haram menurut agama Islam, tetapi harus jujur kalau halal harus punya label halal, sebaiknya kalau ada unsure haram harus dikatakan itu tidak halal. ${ }^{9}$ Selanjutnya bahwa, membahas Pasal 4 harus dikaitkan juga dengan isi beberapa Pasal yang mengatur sanksi hukum dari pelanggaran masalah kehalalan, seperti :

\section{Pasal 25, menyebutkan :}

Pelaku Usaha yang telah memperoleh Sertifikat Halal wajib:

a. mencantumkan Label Halal terhadap Produk yang telah mendapat Sertifikat Halal;

b. menjaga kehalalan Produk yang telah memperoleh Sertifikat Halal;

c. memisahkan lokasi, tempat dan penyembelihan, alat pengolahan, penyimpanan, pengemasan, pendistribusian, penjualan, dan penyajian antara Produk Halal dan tidak halal;

d. memperbarui Sertifikat Halal jika masa berlaku Sertifikat Halal berakhir; dan e. melaporkan perubahan komposisi Bahan kepada BPJPH.

Pasal 25 Undang-Undang Nomor 33 Tahun 2014 “ kewajiban pemegang sertifikat halal untuk menyematkan label halal pada produk. Selain itu, pun harus menjaga kehalalan, memperpanjang masa berlaku sertifikat, serta membedakan proses pembuatan produk halal dan tidak halal. Pelaku usaha juga wajib melapor

9 Siti Aminah, Pada Seminar “ Menuju 2019 Wajib Halal” Cukupkah Satu tahun Mempersiapkan Sertifikasi Halal yang di selenggarakan Policy Research and Bisnis Strategy, di Hotel Prabu Jakarta, pada tanggal 24 januari 2018 
jika ada pengubahan komposisi bahan baku.Adapun sanksinya kalau pemegang sertifikat melanggar pasal tersebut.

Menurut Pasal 22 Undang-Undang Nomor 33 Tahun 2014, ada tiga jenis hukuman yang diberikan bagi pelanggar.

a.berupa peringatan tertulis.

b.denda administratif dan

c.pencabutan sertifikat halal.

\section{Selanjutnya Pasal 26, menyebutkan ;}

(1) Pelaku Usaha yang memproduksi Produk dari Bahan yang berasal dari Bahan yang diharamkan sebagaimana dimaksud dalam Pasal 18 dan Pasal 20 dikecualikan dari mengajukan permohonan Sertifikat Halal.

(2) Pelaku Usaha sebagaimana dimaksud pada ayat (1) wajib mencantumkan keterangan tidak halal pada produknya.

Pengertian dari pasal ini adalah bahwa setiap produk yang akan diedarkan harus halal, dengan mencantumkan label halal dari MUI dan BPJPH.

Yang dimaksud dengan "keterangan tidak halal" adalah pernyataan tidak halal yang merupakan bagian tidak terpisahkan dari Produk. Keterangan dapat berupa gambar, tanda, dan/atau tulisan. Pasal ini tidak diartikan bahwa di Indonesia tidak boleh ada produk yang haram untuk diperjualkan, tetapi bagi yang tidak halal maka tidak perlu disertifikasi halal, tetapi cukup dengan memberi label tidak halal.

\section{Adapun kriteria produk tidak halal terdapat dalam Pasal 18.}

Yang berbunyi :

(1) Bahan yang berasal dari hewan yang diharamkan sebagaimana dimaksud dalam Pasal 17 ayat (3) meliputi:

1. bangkai;

2. darah;

3. babi; dan/atau

4. hewan yang disembelih tidak sesuai dengan syariat.

(2) Bahan yang berasal dari hewan yang diharamkan selain sebagaimana dimaksud pada ayat (1) ditetapkan oleh Menteri berdasarkan fatwa MUI. “ 
Sedangkan sanksi pelanggaran ketentuan ini berdasarkan Pasal 27 UU Nomor 33 Tahun 2014, yaitu :

a. sanksi teguran lisan,

b.peringatan tertulis, dan

c.denda administratif

Mengingat mayoritas rakyat Indonesia adalah masyarakat Islam, yang sangat membutuhkan perlindungan dari Negara terhadap barang-barang yang tidak halal dan tidak mempunyai lebel halal, maka Negara mengajak masyarakat untuk berperan serta melakukan pengawasan terhadap produk-produk yang bererdar dipasaran baik dari luar maupun dalam negeri, bahkan Negara akan memberikan penghargaan kepada masyarakat yang ikut serta secara aktif dalam Pengawasan tersebut.

Seperti yang disebutkan dalam Pasal 53 yaitu:

(1) Masyarakat dapat berperan serta dalam penyelenggaraan JPH.

(2) Peran serta masyarakat sebagaimana dimaksud pada ayat (1) dapat berupa:

a. melakukan sosialisasi mengenai JPH; dan

b. mengawasi Produk dan Produk Halal yang beredar.

(3) Peran serta masyarakat berupa pengawasan Produk dan Produk Halal yang beredar sebagaimana dimaksud pada ayat (2) huruf b berbentuk pengaduan atau pelaporan ke BPJPH.

\section{Selanjutnya Pasal 54, menyebutkan :}

BPJPH dapat memberikan penghargaan kepada masyarakat yang berperan serta dalam penyelenggaraan JPH.

Sebagai wujud apresiasi maka BPJPH sebagai lembaga penyelenggara Jaminan Produk Halal dapat memberikan penghargaan kepada masyarakat yang berperan aktif dalam penyelenggaraan Jaminan Produk Halal.

\section{Jaminan Produk Halal}

Pemerintah bertanggung jawab dalam menyelenggarakan Jaminan Produk Halal (JPH), secara aman, nyaman dan melindungi konsumen dalam mengkonsumsi dan menggunakan produk. Penyelenggara Jaminan produk halal ini dilakukan oleh Badan Penyelenggara Jaminan Produk Halal (BPJPH). 
Pemerintah membentuk Badan Penyelenggara Jaminan Produk halal yang menerbitkan dan mencabut sertifikat Halal dan label halal.

Di Indonesia, kesadaran akan produk halal sudah menjadi bagian dari kebutuhan kehidupan masyarakat yang mayoritas muslim, sehingga sangat mudah untuk menemukan produk halal di Indonesia. Bahkan lebih mudah untuk mendapatkan yang halal dari pada yang haram. Namun di tengah-tengah melimpahnya produk halal, tidak jarang muncul produk haram, terutama yang dihasilkan oleh pabrik moderen. Masyarakat tidak mudah mengenali halal haramnya, dengan demikian orientasi sertifikasi halal di Indonesia didominasi oleh motivasi untuk melindungi masyarakat muslim.

Untuk mencapai semua itu, perlu diselenggarakan suatu sistim pangan yang memberikan perlindungan bagi yang memproduksi maupun yang mengonsumsi pangan. Pasal 97 UU Pangan tersebut memerintahkan kepada setiap orang yang memproduksi dan memperdagangkan pangan di dalam negeri untuk mencantumkan label di dalam dan/atau pada kemasan pangan, dan salah satu label yang wajib dicantumkan adalah label halal, sebagaimana disebutkan pada Pasal 7 ayat (3) huruf e UU Pangan.

Selain UU Pangan ketentuan label halal juga diatur dalam Peraturan Pemerintah No. 69 tahun 1999 tentang Label dan Iklan, dimana dalam penjelasan Pasal 10 ayat (1) PP tersebut menyatakan bahwa pencantuman keterangan halal atau tulisan "halal" pada label pangan merupakan kewajiban apabila pihak yang memproduksi dan atau memasukkan pangan kedalam wilayah Indonesia menyatakan produknya halal bagi umat Islam. Namun apabila dilihat lebih lanjut dari penjelasan Pasal 11 ayat (1) PP tersebut terdapat pertentangan, dimana pencantuman tulisan halal pada dasarnya bersifat sukarela. Jadi intinya keharusan untuk mencantumkan label halal pada saat itu belum menjadi sesuatu yang sifat urgensi, sehingga dapat dikatakan bahwa regulasi yang ada pada saat itu belum memberikan jaminan kepastian hukum terhadap produk pangan halal bagi konsumen muslim di Indonesia, fakta tersebut tidak sejalan dengan amanat UU No.8 tahun 1999 tentang Perlindungan Konsumen.

Lahirnya UU JPH, maka urgensi atas sertifikasi halal, bukan lagi menjadi tanggung jawab MUI saja tetapi menjadi tanggung jawab bersama antara 
pemerintah dan MUI. Implementasi sistim Jaminan Halal merupakan langkah berbagi tanggung jawab, sebagai manifestasi sharing responsibillity, agar jangan sampai diartikan bahwa sertifikat halal itu sepenuhnya menjadi tanggung jawab pihak MUI semata. ${ }^{10}$

MUI dan pemerintah memiliki peran masing-masing sehingga tidak ada tumpang tindih. Dalam proses sertifikasi halal, MUI melalui LPPOM MUI berwenang pada proses pengecekan dan pemeriksaan (audit halal). Sementara itu, pemerintah melalui Kementerian Agama ada dibagian administrasi, pengawasan, dan penindakan. Pada proses berikutnya, penetapan fatwa halal tetap berada di ranah MUI, seperti sebelumnya. Lewat UU JPH, pemerintah memiliki peran untuk menindak sektor perusahaan yang melakukan pelanggaran terkait produk atau pangan lainnya.

Pemberlakuan UU JPH, menimbulkan beberapa konsekuensi sekaligus tantangan, yakni :

a. adanya sifat wajib sertifikasi halal yang bertujuan agar adanya kejelasan bahwa yang halal adalah yang benar-benar halal sesuai kriteria halal.

b. produk yang tidak halal harus dinyatakan tidak halal. Artinya semua produk yang beredar di Indonesia wajib bersertifikat halal. ${ }^{11}$

Jika ada perusahaan yang mengaku produknya halal namun tidak dilengkapi dengan dokumen halal maka bisa dijerat dengan pasal tindak pidana. Dengan mendapatkan sertifikat halal bukan tanggung jawab perusahaan atas kehalalan produk berhenti sampai disitu, tetapi justru pihak perusahaan tetap bertanggung jawab untuk menjamin dan menjaga kehalalan produk yang dihasilkannya dengan konsisten, dalam sistim jaminan halal dan mengimplementasikannya.

\footnotetext{
${ }^{10}$ Ragam Berita, Jaminan Halal Tanggung Jawab Bersama, Jurnal Halal No.121 tahun 2016, hlm.43

${ }^{11}$ Tanya Jawab, Konsekuensi Pemberlakuan UU JPH, Jurnal Halal No.126 tahun 201, hlm. 18
} 
TABEL

Kesadaran Masyarakat Terhadap Produk Halal

\begin{tabular}{|c|c|c|}
\hline $\mathrm{NO}$ & PERTANYAAN & JAWABAN \\
\hline 1 & $\begin{array}{l}\text { Menurut saudara, pentingkah terhadap suatu produk } \\
\text { makanan dilakukan penyertifikasian halal? }\end{array}$ & $\begin{array}{l}90 \% \\
\text { menjawab } \\
\text { Penting }\end{array}$ \\
\hline 2 & $\begin{array}{l}\text { Menurut saudara, apakah setiap produk makanan baik } \\
\text { yang diproduksi didalam negeri maupun yang datang } \\
\text { dari luar negeri harus dilakukan sertifikasi halal }\end{array}$ & $\begin{array}{l}95 \% \\
\text { menjawab } \\
\text { YA }\end{array}$ \\
\hline 3 & $\begin{array}{l}\text { Menurut saudara, sudahkah sertifikasi halal atas suatu } \\
\text { produk makanan dilakukan secara konsisten dalam } \\
\text { rangka perlindungan konsumen }\end{array}$ & $\begin{array}{l}50 \% \\
\text { menjawab } \\
\text { belum }\end{array}$ \\
\hline 4 & $\begin{array}{l}\text { Menurut saudara, apakah lahirnya undang-undang } \\
\text { nomor } 33 \text { tahun } 2014 \text { tentang Jaminan Produk Halal } \\
\text { menjadi jaminan bahwa suatu produk itu halal }\end{array}$ & $\begin{array}{l}67 \% \\
\text { menjawab } \\
\text { tidak }\end{array}$ \\
\hline 5 & $\begin{array}{l}\text { Tahukah saudara bahwa sertifikasi produk halal yang } \\
\text { selama ini dipegang oleh MUI beralih ke Kementrian } \\
\text { Agama sebagai pelaksana amanat undang-undang }\end{array}$ & $\begin{array}{l}57 \% \\
\text { menjawab } \\
\text { belum tahu }\end{array}$ \\
\hline 6 & $\begin{array}{l}\text { Tahukah saudara bahwa untuk pelaksanaan sertifikasi } \\
\text { kehalalan produk, Kementrian Agama telaah } \\
\text { memebntuk Badan Penyelenggara Jaminan Produk Halal } \\
\text { (BPJHJ) }\end{array}$ & $\begin{array}{l}76.7 \% \\
\text { menjawab } \\
\text { Tahu }\end{array}$ \\
\hline 7 & $\begin{array}{l}\text { Dalam undang-undang nomor } 33 \text { tahun } 2014 \text { tentang } \\
\text { Jaminan Produk Halal, selain BPJHJ, dibentuk pula } \\
\text { Lembaga pemeriksa Halal (LPH), yang dibentuk antara } \\
\text { pemerintah dan masyarakat. Bila nanti anda terpilih } \\
\text { menjadi anggota LPH tersebut, bersediakah anda }\end{array}$ & $\begin{array}{l}75 \% \\
\text { menjawab } \\
\text { bersedia }\end{array}$ \\
\hline 8 & $\begin{array}{l}\text { Menurut saudara, sudah tepatkah solusi yang diberikan } \\
\text { pemerintah denagn membentuk badan badan tersebut } \\
\text { dalam rangka melindungi konsumen atas produk halal? }\end{array}$ & $\begin{array}{l}80 \% \\
\text { menjawab } \\
\text { sudah tepat }\end{array}$ \\
\hline 9 & $\begin{array}{l}\text { Menurut saudara, perlukah ada sosialisasi mengenai } \\
\text { sertifikasi produk halal ini }\end{array}$ & $\begin{array}{l}98 \% \\
\text { menjawab } \\
\text { perlu }\end{array}$ \\
\hline 10 & $\begin{array}{l}\text { Apakah saudara akan mendukung program-program } \\
\text { yang diadakan oleh pemerintah dalam rangka } \\
\text { menyosialisasikan setifikasi produk halal ini }\end{array}$ & $\begin{array}{l}100 \% \\
\text { menjawab } \\
\text { mendukung }\end{array}$ \\
\hline
\end{tabular}

Analisis terhadap hasil jawaban kuesioner responden, menunjukkan bahwa masyarakat muslim menginginkan adanya jaminan perlindungan produk halal dari pemerintah segera. Karena dalam prakteknya masih banyak beredar dimasyarakat produk yang tidak halal, bahkan sekarang banyak produk yang masuk dari luar negeri. 


\section{Peran Negara dan Peran Masyarakat dalam pelaksanaan Jaminan Produk Halal.}

Keterangan tentang kehalalan pangan mempunyai arti yang sangat penting bagi masyarakat muslim, dimana berdasarkan survey data yang penulis peroleh hampir 95\% (dari 60 kuisioner yang ditujukan pada konsumen muslim) menyatakan bahwa terhadap produk makanan atau produk pangan baik yang diproduksi di dalam negeri maupun yang didatangkan dari luar negeri wajib dilakukan pensertifikasian halal, yang salah satunya ada penglabelan halal yang dikeluarkan oleh suatu lembaga yang berwenang.

Kewajiban mencantumkan label halal ini kemudian diakomodir dengan lahirnya UU 33 tahun 20014 tentang Jaminan Produk Halal. Lahirnya undangundang ini dimaksudkan untuk mewujudkan kewajiban negara dalam memberikan perlindungan dan jaminan tentang kehalalan produk yang dikonsumsi dan digunakan oleh masyarakat, sehingga tercapai ketenangan bagi umat Islam dalam peribadatannya dan dalam menjalankan ajaran agamanya. Konsumsi produk halal merupakan kewajiban yang tidak hanya berhubungan dengan religiusitas tetapi juga dapat mencegah mereka dari neraka,penyakit dan godaan setan. ${ }^{12}$ Namun menurut $67 \%$ data yang penulis peroleh menyatakan bahwa dengan lahirnya undang-undang tersebut belum menjadi jaminan bahwa suatu produk itu halal.

Karenanya untuk melaksanakan penyelenggaraan Jaminan Produk Halal (JPH) tersebut, UU JPH mengamanatkan pembentukan Badan Penyelenggara Jaminan Produk Halal (BPJPH) yang memiliki wewenang untuk :

a. merumuskan dan menetapkan kebijakan JPH;

b. menetapkan norma, standar, prosedur, dan kriteria JPH;

c. menerbitkan dan mencabut Sertifikat Halal dan Label Halal pada Produk;

d. melakukan registrasi sertifikat halal pada produk luar negeri;

e. melakukan sosialisasi, edukasi dan publikasi produk halal;

f. melakukan akreditasi terhadap LPH; g. Melakukan registrasi Auditor Halal;

h. melakukan Pengawasan terhadap JPH;

${ }^{12}$ Ahmad Sarwat, Halal atau Haram : Kejelasan Menuju Keberkahan, Jakarta : Gramedia, 2013),hlm.2-5 
i. melakukan pembinaan auditor halal; j. melakukan kerja sama dengan lembaga dalam dan luar negeri di bidang penyelenggaraan JPH.

Sebelum berlakunya UU JPH, wewenang BPJPH ini dilakukan oleh LPPOM MUI, yakni melakukan pemeriksaan kehalalan produk. Pada awal berdirinya di tahun 1990, dalam menjalankan kewenangannya, lembaga ini banyak mengalami masalah, dimana banyak yang menganggap bahwa proses sertifikasi halal itu terlalu mengada-ada dan memberatkan kalangan industri, bahkan ada pihak perusahaan mempertanyakan apakah benar sertifikasi yang dilakukan LPPOM MUI dapat diterima oleh masyarakat, yang pada saat itu pemahaman masyarakat tentang urgensi pangan halal dengan sertifikasi halal masih sangat dini. Hal ini terjadi karena kurangnya sosialisasi mengenai sertifikasi produk halal sebagaimana terlihat dari data yang penulis peroleh dimana $98 \%$ menyatakan perlu adaya sosialisasi mengenai produk halal. Selain itu masih banyaknya perusahaan yang mempertanyakan kapasitas personal maupun otoritas kelembagaan melakukan audit, bagaimana bisa lembaga keagamaan seperti MUI dapat melakukan audit dilingkup industri dengan teknologi yang canggih pula.

Hasil sosialisasi intensif dan ekstensif, serta upaya yang ekstra gigih, titik cerah perkembangan sertifikasi halal mulai terlihat secara progresif, setelah terjadinya kasus MSG, dimana perusahaan yang tadinya sudah memperoleh sertifikasi halal untuk jangka waktu 2 tahun, dibatalkan sertifikasi halalnya oleh MUI karena terbukti melakukan pelanggaran dalam produksinya dan akibat pencabutan tersebut mengakibatkan perusahaan tersebut nilai sahamnya anjlok di pasaran. Dan bila dilihat dari kejadian ini maka dapat diketahui urgensinya dari suatu sertifikasi halal atas suatu produk atau pangan sebagai jaminan produk halal. $^{13}$

Urgensi atas sertifikasi halal, semakin membawa dampak yang signifikan, dimana kebutuhan dan permintaan akan sertifikasi halal semakin melonjak dratis, bukan hanya secara domestik tetapi juga di pasar global, sebagaimana dikehendaki oleh 98\% masyarakat muslim. Menurut hasil penelitian penulis

13 Profil Auditor, Sertifikasi Halal Tidak Lagi Dipandang Sebelah Mata, Jurnal Halal No.121 tahun 2016, hlm.20 
yang menghendaki adanya pesertifikasian halal atas suatu produk dan menganggap hal tersebut adalah hal penting yang harus dilakukan negara.

Dalam menjalankan kewenangannya tersebut, BPJPH tidak berdiri sendiri tetapi berdasarkan Pasal 7 UU JPH, lembaga tersebut bersinergi dengan denagn lembaga lain, yaitu:

a. Kementerian dan/atau lembaga terkait;

b. Lembaga Pemeriksa Halal yang bertugas untuk melakukan pemeriksaan dan/atau pengujian produk; dan

c. MUI. Kerjasama BPJPH bersama MUI dilakukan dalam bentuk :

1) sertifikasi auditor halal;

2) penetapan kehalalan produk, yang dikeluarkan dalam bentuk Keputusan Penetapan Halal; dan

3) akreditasi Lembaga Pemeriksa Halal.

Untuk mejalankan kewenangannya tersebut BPJPH membuat Program dalam menyelenggarakan jaminan produk halal adalah:

1. Sertifikasi halal

2. Registrasi halal (untuk produk luar negeri)

3. Pembinaan Jamiman Produk Halal

4. Pengawasan Jaminan Produk Halal

5. Kerjasama Jaminan Produk Halal

6. Standardisasi Jaminan Produk Halal

Sebelum terbentuknya Peraturan Presiden sebagaimana diamanatkan UU No.33 tahun 2014, dalam menjalankan tugas dan fungsinya tersebut BPJPH bersandar pada 2 (dua) regulasi turunan yang sudah memuat tentang BPJPH, yakni : ${ }^{14}$

a. Perpres yang mengatur tentang BPJPH sudah terbit pada tahun 2015, yaitu perpres No. 83 tahun 2015 tentang Kementerian Agama, yg didalamnya juga memuat tentang BPJPH, dan

b. Peraturan Menteri Agama (PMA) tentang Stuktur Kementerian Agama yang didalamnya memuat BPJPH, yaitu: PMA No. 42/Tahun 2016.

${ }^{14}$ Hasil wawancara dengan Ibu Lady Yulia, Kasubag Sistim Informasi dan Humas BBPJH ,pada tanggal 3 Mei 2018 
Dengan bersandar pada dua regulasi tersebut, BPJPH membuat kebijakankebijakan dalam melaksanakan amanat UU no. 33 tahun 2014, antara lain :

- BPJPH bersama BSN dan sejumlah Kementerian lainnya menyiapkan sejumlah standar JPH yang dibutuhkan pada implementasi UU JPH, diantaranya yang sudah ditetapkan SNI 99001 tentang Manajemen Halal. Sedangkan standar-standar yang lain dalam proses penyelesaian.

- Sejumlah draf Peraturan Menteri Agama telah kita siapkan menunggu pengesahan RPP oleh Presiden.

- Kebijakan-kebijakan teknis lainnya terkait operasional BPJPH sedang dalam proses penyiapan, termasuk mengenai sistem IT dan lain sebagainya.

Pemerintah Solusi yang diberikan oleh pemerintah dalam rangka perlindungan konsumen atas jaminan produk halal dengan membentuk dan mengfungsikan lembaga BPJPH, sebagaimana hasil penelitian melalui quesionner, kepada responden muslim $\mathbf{7 6 , 7 \%}$ adalah sudah tepat dan $57 \%$ nya menyatakan belum mengetahui adanya peralihan pelaksana atas sertfikasi halal atas produk dari MUI ke Kementerian Agama sebagai lembaga yang menaungi BPJPH.

Adapun menjadi kewenangan BPJPH, sebagai lembaga yang berada dibawah Kementerian Agama, yaitu :

a. Merumuskan dan menetapkan kebijakan JPH

b. Menetapkan norma, standar, prosedur, dan kriteria JPH,

c. Menerbitkan dan mencabut Sertifikat Halal dan Label Halal pada Produk,

d. Melakukan registrasi sertifikat halal pada produk luar negeri,

e. Melakukan sosialisasi, edukasi dan publikasi produk halal,

f. Melakukan akreditasi terhadap LPH,

g. Melakukan registrasi Auditor Halal,

h. Melakukan Pengawasan terhadap JPH,

i. Melakukan pembinaan auditor halal

j. Melakukan kerja sama dengan lembaga dalam dan luar negeri di bidang penyelenggaran JPH. 
Selain MUI, dalam mejalankan pensertifikasian halal atas produk BPJPH dibantu oleh Lembaga Pemeriksa Halal (LPH), yang bertugas melakukan pemeriksaan dan/atau pengujian terhadap produk, setelah berkas dinyatakan lengkap oleh BPJPH, dan dalam jangka waktu paling lama 5 (lima) hari kerja terhitung sejak dokumen permohonan dinyatakan lengkap,dan LPH tersebut harus menyampaikan hasilnya kepada BPJPH dalam bentuk penetapan LPH. Untuk selanjutnya dibuatkannya penetapan kehalalan produk oleh MUI melalui sidang fatwa halal, dan berdasarkan penetapan kehalalan produk yang dikeluarkan oleh MUI tersebut diterbitkan sertifikat halal oleh BPJPH.

Dari proses sertifikasi halal tersebut dapat dilihat bahwa LPH memegang peranan yang penting, sebagai lembaga yang didirikan oleh masyarakat, bertugas memeriksa/atau menguji produk itu sendiri, apakah suatu produk itu halal secara syariat (artinya tidak diharamkan oleh agama), dan disembelih sesuai dengan syariat dan memenuhi kaidah kesejahteraan hewan serta kesehatan masyarakat veteriner (untuk hewan), serta apakah tumbuhan yang dikelola tersebut memabukkan dan/atau membahayakan kesehatan bagi orang yang mengkonsumsinya dan/atau terkontaminasi dengan bahan yang diharamkan. Jadi terlihat peran LPH melalui penetapan menjadi dasar dikeluarkannya sertifikat halal produk.

Dengan peran yang besar tersebut, dalam pendiriannya sebagaimana ditentukan dalam pasal 13 UU 33 tahun 2014 menentukan bahwa LPH tersebut harus :

a.Memiliki kantor sendiri dan perlengkapannya;

b.Memiliki akreditasi dari BPJPH;

c.Memiliki auditor halal palig sedikit 3 (tiga) orang;

d.Memliki laboratorium atau kespakatan kerasama dengan lembaga lain yang memiliki laboratorium

Selain syarat di atas, LPH juga harus diajukan oleh lembaga keagamaan Islam berbadan hukum. Artinya LPH yang didirikan oleh masyarakat tersebut dalam memperoleh akreditasi dari BPJPH harus diajukan oleh lembaga keagamaan Islam yang berbadan hukum. 
Hal ini memperlihatkan bahwa kehalalan suatu produk bukan hanya menjadi tanggungjawab pemerintah tetapi juga menjadi tanggung jawab masyarakat. Ikut sertanya masyarakat dalam tercapainya perlindungan atas produk halal merupakan hal yang sangat diharapkan, terutama dalam rangka mendukung program-program yang diadakan oleh pemerintah dalam rangka mensosialisasikan tentang sertifikasi produk halal, sehingga hal ini dapat menjadi pemicu bagi pengusaha produk-produk makanan untuk segera melakukan sertifikasi kehalalan produknya. Dan antusias masyarakat terhadap program ini terlihat dari data yang penulis peroleh dimana 75\% masyarakat muslim bersedia untuk menjadi anggota LPH, dan 100\% bersedia untuk mendukung program-program pemerintah terkait sosialisasi sertifikasi produk halal. Hasil penelitian penulis bahwa masyarakat berkeinginan untuk membantu pemerintah dalam penyelenggaraan jaminan Produk Halal. Dan antusias masyarakat terhadap program ini terlihat dari data yang penulis peroleh dimana 75\% masyarakat muslim bersedia untuk menjadi anggota LPH, dan $100 \%$ bersedia untuk mendukung program-program pemerintah terkait sosialisasi sertifikasi produk halal.

\section{D.Sanksi Pidana dalam UU JPH}

\section{Pasal 56}

Pelaku Usaha yang tidak menjaga kehalalan Produk yang telah memperoleh Sertifikat Halal sebagaimana dimaksud dalam Pasal 25 huruf b dipidana dengan pidana penjara paling lama 5 (lima) tahun atau pidana denda paling banyak Rp2.000.000.000,00 (dua miliar rupiah).

Pasal ini dimaksudkan kepada para pengusaha yang sudah mendapatkan sertifikasi halal kemudian tidak menjaga dan mengawasi kehalalan produknya dipasaran, maka Pasal 56 akan dikenakan pada pengusaha tersebut.

\section{Pasal 57}

Setiap orang yang terlibat dalam penyelenggaraan proses JPH yang tidak menjaga kerahasiaan formula yang tercantum dalam informasi yang diserahkan Pelaku Usaha sebagaimana dimaksud dalam Pasal 43 dipidana dengan pidana penjara paling lama 2 (dua) tahun atau pidana denda paling banyak Rp2.000.000.000,00 (dua miliar rupiah). 
Adapun Sasaran pokok ketentuan larangan tersebut, adalah semata terhadap pelaku orang perseorangan. Oleh karena itu, ketentuan atau norma pidana atas Jaminan Produk Halal, merupakan peraturan tentang hukuman akibat pelanggaran kewajiban moral hazard dari subjek hukum pribadi atau korporasi.

\section{PENUTUP}

\section{Kesimpulan}

Peran Negara dalam Pelaksanaan Pasal 4 UU No.33 Tahun 2014 tentang Jaminan Produk Halal, Semula oleh lembaga MUI (Majelis Ulama Indonesia). Tetapi sejak diundangkannya UU.No.33 Tahun 2014 tentang Jaminan Produk Halal wewenang tersebut dialihkan kepada Badan Penyelenggara Jaminan Produk Halal (BPJPH) sejak Oktober tahun 2017. Dalam rangka menjamin pelaksanaan penyelenggaraan Jaminan Produk Halal, BPJPH melakukan pengawasan terhadap Lembaga Penjamin Halal; masa berlaku Sertifikat Halal; kehalalan Produk; pencantuman Label Halal; pencantuman keterangan tidak halal; pemisahan lokasi, tempat dan alat pengolahan, penyimpanan, pengemasan, pendistribusian, penjualan, serta penyajian antara Produk Halal dan tidak halal; keberadaan Penyelia Halal; dan/atau kegiatan lain yang berkaitan dengan JPH Untuk menjamin penegakan hukum terhadap pelanggaran Undang-Undang ini, ditetapkan sanksi administratif dan sanksi pidana. Peran serta Masyarakat dalam Jaminan Produk Halal sangat diharapkan pemerintah. Terbukti ada 2 Pasal yang mengatur dan mengajak masyarakat untuk berperan serta dalam mengawasi peredaran produk halal. Sanksi Pidana bagi pelanggaran UU JPH, Pasal 56 dan Pasal 57 UU JPH. Hasil penelitian penulis bahwa masyarakat berkeinginan untuk membantu pemerintah dalam penyelenggaraan jamianan Produk Halal. Dan antusias masyarakat terhadap program ini terlihat dari data yang penulis peroleh dimana $75 \%$ masyarakat muslim bersedia untuk menjadi anggota LPH, dan 100\% bersedia untuk mendukung program-program pemerintah terkait sosialisasi sertifikasi produk halal. 


\section{Saran}

1. Segera dilakukan sosialisasi UU Jaminan Produk Halal, karena semakin banyaknya barang -barang dari produk luar negeri yang tidak jelas kehalalannya, sehingga masyarakat lebih waspada dan hati-hati.

2. Pemerintah ( Negara) dalam hal ini Badan Pengawas Jaminan Produk Halal (BPJPH) melakukan pengawasan Ekstra kepada para produsen atau pelaku usaha yang akan mengedarkan barangnya kepada konsumen untuk membedakan mana barang yang halal dan tidak halal, sesuai dengan keinginan masyarakat muslim.

3. Dalam UU No.33 Tahun 2004 tentang Jaminan Produk Halal ini, belum diatur Sanksi hukum untuk pelaku usaha yang tidak mengajukan sertifikasi, untuk itu pemerintah segara membuat aturan terbaru untuk memberikan sanksi kepada pelaku Usaha yang tidak mengajukan sertifikasi Halal. 


\section{DAFTAR PUSTAKA}

\section{BUKU}

Al Gazali, Imam, Benang Tipis Antara Halal dan Haram, Surabaya : Putra Pelajar, 2002

Ahmad Sarwat, Halal atau Haram : Kejelasan Menuju Keberkahan, Jakarta : Gramedia, 2013

Bernard L. Tanya, Teori Hukum : Strategi Tertib Manusia Lintas Ruang dan Generasi, Yogyakarta : Genta, 2010

Mashudi,H. Konstruksi Hukum dan Respon Masyarakat Terhadap Sertifikasi Produk Halal, Yogjakarta : Pustaka Pelajar, 2015

Tim Dosen Kewarganegaraan, Modul Pendidikan Kewarganegraan Untuk Mahasiswa, Jakarta :Dikti, 2016

\section{ARTIKEL}

Profil Auditor, Sertifikasi Halal Tidak Lagi Dipandang Sebelah Mata, Jurnal Halal No.121 tahun 2016, hlm.20

Tanya Jawab, Konsekuensi Pemberlakuan UU JPH, Jurnal Halal No.126 tahun 201, hlm.18

Siti Aminah, Pada Seminar “ Menuju 2019 Wajib Halal” Cukupkah Satu tahun Mempersiapkan Sertifikasi Halal yang di selenggarakan Policy Research and Bisnis Strategy, di Hotel Prabu Jakarta, pada tanggal 24 Januari 2018

\section{PERATURAN}

Undang-Undang Nomor 8. Tahun 1999 Tentang Perlindungan Konsumen

Undang-Undang Nomor 33 Tahun 2014 Tentang Jaminan Produk Halal

\section{INTERNET}

http://www.tribunnews.com/bisnis/2017/10/14/mulai-2019. Sertifikasi-halal dipegang- kemenag-tidak lagi oleh mui.

http://www.tribunnews.com/bisnis/2017/10/13/mulai-2019-sertifikasi- $\quad$ produkhalal-jadi-kewajiban-dan-akan-dijalankan-kemenag.

http://www.tempo.co/bisnis/2017/10/15/Pemerintah Bentuk BPJPH, Ini Cara Mendapatkan Sertifikat Halal, 